\title{
CARDIAC EFFECTS OF MAGNESIUM WITH SPECIAL REFERENCE TO ANAESTHESIA: A REVIEW
}

\author{
BARRY S. KRASNER
}

ISCHAEMIC HEART DISEASE is a major health problem throughout the Western World. In the United States more than 650,000 people die annually from coronary artery disease; approximately 1.3 million people have a myocardial infarction each year; and many suffer from the complications of ischaemic heart disease.'

The anaesthetist is often presented with a patient suffering from latent or known ischaemic heart disease who is to undergo a surgical operation. In order to prevent perioperative morbidity and mortality as little interference as possible with myocardial metabolism is imperative. A fine balance between the myocardial oxygen supply and myocardial oxygen demand must be preserved during anaesthesia and operation. ${ }^{2}$

The effects of potassium and calcium on normal cardiac function have been well documented and established but little attention has been focused on the importance of magnesium in the maintenance of cardiac homeostasis. Although the element magnesium was first isolated as early as 1808 by the English chemist Sir Humphrey Davy and experimental work by Samuel J. Meltzer was carried out in 1897 at the Rockefeller Institute using magnesium sulphate in animals, only recently has a great deal of evidence accumulated which undoubtedly proves the importance of magnesium for the functional and structural integrity of cardiac muscle. In this communication we will examine the importance of myocardial magnesium with particular reference to ischaemia.

\section{Myocardial metabolism and magnesium}

The importance of magnesium in maintaining mitochondrial integrity and in retaining myocardial potassium has been described by Seelig. ${ }^{3}$ Magnesium is involved in normal mitochondrial contraction with formation of the compact $\mathrm{Mg}$ ATP complex and is involved in the electron

Barry S. Krasner, M.D., M.B., Ch.B., F.F.A.R.C.S., Consultant Anesthesiologist, Lenox Hill Hospital, 100 East 77th Street, New York, New York 10021.

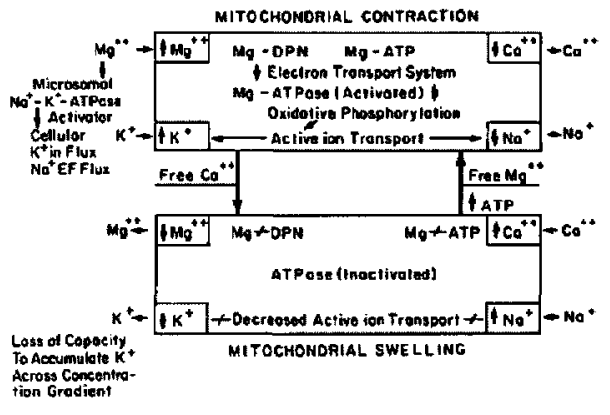

Figure I Schematic representation of the role of magnesium in mitochondrial contraction and mitochondrial swelling.

transport system (Figure 1). Magnesium ions stimulate adenosine triphosphatase (A.T.P.ase) which in turn activates cellular potassium influx and sodium efflux. With depletion of cardiac magnesium, whether from ischaemia, anoxia or cardiotoxic drugs, Adenosine tri-phosphatase becomes inactivated and oxidative phosphorylation is inhibited. Cellular potassium efflux and sodium infiux takes place and mitochondrial swelling occurs, ultimately resulting in myocardial fibre necrosis. Heggtveit, et al. ${ }^{4}$ have shown that the concentration of magnesium in human heart muscle is decreased after death. Both acutely infarcted heart muscle and non-infarcted areas showed a decrease in magnesium levels. Skeletal muscle magnesium levels and potassium concentrations remained normal in this study. Chipperfields confirmed these findings. This suggests that patients who have lower than normal magnesium concentrations in heart muscle would be more likely to die suddenly from myocardial infarction.

Administration of magnesium salts has been shown to reverse many of the changes in animal models of heart disease. There is also good evidence from animal studies by Jankes, et $a l .^{6}$ and from human studies by Krasner and Girdwood ${ }^{7}$ that preoperative treatment with magnesium could protect the heart against myocardial necrosis and arrhythmias. 

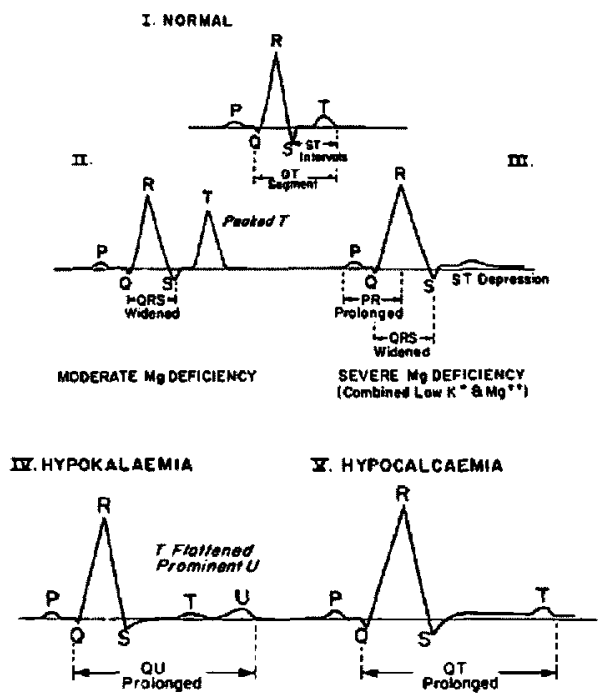

Flaure 2 Effect of magnesium deficiency on the electrocardiogram compared with the changes associated with hypokalacmia and hypocalcaemia.

\section{Magnesium and the electrocardiogram}

Studies by Vitale, et al ${ }^{8.9}$ and $\mathrm{Ono}^{10}$ have demonstrated that early electrocardiographic signs of magnesium deficiency show slightly widened QRS complexes, peaked $T$ waves and ST segment depression. As the magnesium deficiency becomes more severe the QRS complex widens and conduction disturbances and arrhythmias occur (Figure 2).

\section{Magnesium and the $Q T_{c}$ interval}

$\mathrm{QT}_{\mathrm{c}}$ is the QT complex, which is the interval measured from the beginning of the QRS complex to the end of the $T$ wave. It represents the total duration of yentricular systole, i.e. the combined phases of depolarisation and repolarisation."

QT intervals of the electrocardiograph are clinically important and $\mathrm{Q} \mathrm{QT}_{\mathrm{t}}$ interval should not exceed 0.42 second in men and 0.43 second in women. ${ }^{12}$

It is known that a prolonged $\mathrm{QT}_{\mathrm{c}}$ interval results from delayed repolarization of the ventricular myocardium. It is during this period that the patient is highly vulnerable to cardiac arrhythmias with myocardial infarction and death. Schwartz ${ }^{1}$ has predicted that certain individuals with congenitally prolonged $\mathrm{QT}_{\mathrm{c}}$ intervals are at an increased risk of fatal ventricular fibrillation when conditions causing hypoxia or sympathetic discharge occur. Interesting work by Davis* on the use of magnesium for angina and case studies by Krasner and Garbert based on measurement of the $\mathrm{QT}_{\mathrm{c}}$ intervals and clinical observations during magnesium therapy for anxiety states, have clearly shown the importance of reducing the $\mathrm{QT}_{\mathrm{f}}$ interval in previously hypomagnesaemic patients (see footnote).

\section{Magnesium deficiency}

The following summary of causes of magnesium deficiency is based partly on work by Wacker and Parisi. ${ }^{14}$

I. Gastrointestinal disorders

Malabsorptions syndromes, including non-tropical sprue

Malabsorptions due to extensive bowel resections

Bowel and biliary fistulae

Prolonged nasogastric suction with administration of magnesium-free parenteral fluids

Prolonged diarrhoea

Protein-calorie malnutrition

Alcoholic cirrhosis

Pancreatitis

II. Endocrine disorders

Hyperparathyroidism and hypoparathyroidism

Hyperaldosteronism

Diabetic coma

III. Renal disease

Glomerulonephritis, pyelonephritis, hydronephrosis, nephrosclerosis and renal uubular acidosis

IV. Diuretic therapy (mercurials, ammonium chloride, and thiazides)

V. Alcoholism

vi. Cardiopulmonary bypass during openheart surgery

VII. Malignant osteolytic disease

VIII. Porphyria with inappropriate secretion of antidiuretic hormone

IX. Excess lactation

*Dr. W.H. Davis has successfully used magnesium in the treatment of hypomagnesemia and angina (personal communication)

$\uparrow$ Dr. B.S. Krasner and Dr. E. Garber (paper entitled "The Importance of Magnesium in General Practice" in progress), have studied the use of magnesium in the treatment of anxiety states. By treating 103 patients, suffering from anxiety states of one form or another, with magnesium, positive results were obtained in $89.3 \%$ of cases. These studies were based on both measurement of the $\mathrm{QT}_{c}$ and on clinical observations. 
$X$. Soft drinking water

XI. Idiopathic

The above list is comprehensive and indicates that hypomagnesaemia is a faily common clinical entity.

\section{Symproms and signs of magnesium deficiency}

The symptoms and signs of magnesium deficiency have been extensively studied both in animals and in human beings ${ }^{15}$ and the problem of well-defined symptomatology still exists.

Predominant features of magnesium deficiency are neuromuscular manifestations. Patients may present with hyper-irritability, muscle weakness, tremor, twitching, cramps, tetany, disorientation, seizures (tonic-clonic or focal) positive Chvostek and Trousseau signs and psychotic behavior.

Case reports by Chadda, et al.16 have sug gested the role of hypomagnesaemia in precipitating tachyarrhythmias. Some of the patients presenting with refractory arrhythmias reverted to sinus rhythm following magnesium therapy.

Electrocardiographic changes due to magnesium deficiency have already been documented earlier in this paper.

Before instituting therapy, one must be absolutely certain that symptoms and signs are not due to other electrolyte disturbances. It is therefore imperative to carry out electrolyte investigations, to correct dehydration, sodium, chloride, potassium and calcium imbalance and the acid-base status of the patient before making a definitive diagnosis of hypomagnesaemia, because the development of symptoms and signs of magnesium deficiency depends not only on the serum magnesium concentration but also on the concentration ratio of magnesium and other ions.

In addition to the evaluation of clinical manifestations of magnesium deficiency, it is important to make the following measurements.

(1) Serum magnesium levels Normal $=1 \mathrm{mmol} / 1(2 \mathrm{mEq} / \mathrm{l})$

(2) Urine magnesium 24-hour determinations Normal $=0.5-4 \mathrm{mmol} / \mathrm{l}(1-8 \mathrm{mEq} / 1)$

Excretion of urinary magnesium is usually low in deficient states $(0.5 \mathrm{mmol} 11 \mathrm{mEq}$ per day)

(3) Red cell magnesium Normal $=2.2-3 \mathrm{mmol} / \mathrm{l}(4.4-6 \mathrm{mEq} / \mathrm{l})$ More accurate in evaluation of magnesium deficiency as compared with serum levels.

(4) Test dose of parenteral administration of magnesium. $5 \mathrm{mmol}(10 \mathrm{mEq})$ of magnesium is injected intramuscularly or intravenously. The urinary excretion of magnesium is then measured twice daily. In a normal subject most of the dose is excreted, while in magnesium deficiency approximately 60 per cent is retained.

Therapeutic guidelines for magnesium deficiency

Based on work by Thoren, ${ }^{17}$ Flink, ${ }^{18}$ and Krasner, ${ }^{7}$ it has become obvious that it may take up to a week to correct the intracellular deficit. An amount of magnesium greater than the probable deficit will be needed to allow for repletion as well as the expected wastage in the urine (and in the bowel if used orally), ${ }^{7}$ and the patient must be treated for a minimum of three or four days.

Randall ${ }^{19}$ has also pointed out that it is important to know the magnesium content of other therapeutic agents in order to prevent magnesium intoxication in patients with uraemia. Good examples are the use of magnesium sulphate as a laxative, and the chronic ingestion of magnesium-containing antacids in patients with impaired renal function.

Magnesium may be administered intramuscularly, intravenously or orally. In this discussion we will confine ourselves to the intramuscular and intravenous routes.

Suggested guidelines are as follows:

1. Intramuscular route (50 per cent $\mathrm{MgSO}_{4}$ solution)

Day $1.2 .0 \mathrm{~g}(16.3 \mathrm{mEq})$ every 2 hours for three doses and then every four hours for four doses.

Day 2. $1.0 \mathrm{~g}(9.1 \mathrm{mEq})$ every four hours for six doses.

Days 3-5. 1.0 g every six hours.

This schedule supplies a total of $32 \mathrm{grams}$ or $260 \mathrm{mEq}$ of magnesium.

2. Intravenous Route (ampoules of 50 per cent $\mathrm{MgSO}_{4}$ )

Day $1.6 .0 \mathrm{~g}(49 \mathrm{mEq})$ in a $1000 \mathrm{ml}$ solution containing glucose plus any other electrolytes and other medications as indicatedinfuse over three hours followed by $5.0 \mathrm{~g}$ in each of two 1 litre solutions to be administered throughout the day.

Day 2. Total of $6.0 \mathrm{~g}(49 \mathrm{mEq})$ divided equally in the total fuids of the day.

Days 3-5. Same as for Day 2.

At this point, it should be emphasized that mag. nesium sulphate should never be infused undiluted, and that regular magnesium estimations be 
carried out in patients receiving magnesium therapy.

\section{Drug interaction and magnesium balance}

Magnesium appears to act directly upon the myoneural junction. Calcium is necessary for the release of acetylcholine from the synaptic vesicles and the motor end-plate. The effect of calcium coupled with acetylcholine is antagonized by magnesium. Elevated levels of magnesium thus reduce the effect of acetylcholine on depolarisation and diminish the excitability of the muscle cell. This is of great importance in certain clinical situations.

Magnesium sulphate is often used in the treatment of pre-eclamptic toxaemia during pregnancy. Gieseke, et al. ${ }^{20}$ and Ghonhein, et al. ${ }^{21}$ have studied the interaction between neuromuscular blocking agents and magnesium both in animals and in man and have demonstrated that magnesium potentiates neuromuscular blockade by both curare and succinylcholine.

It is also possible that in pre-eclamptic or eclamptic patients on magnesium therapy an elevated magnesium concentration could rapidly approach toxic levels. Man usually tolerates high plasma magnesium levels. There are instances, however, when plasma magnesium concentrations well below $5 \mathrm{mmol}(10 \mathrm{mEq})$ per litre can produce abnormal cardiac metabolism resulting in negative inotropic and chronotropic actions. It should be stressed, furthermore, that should any patient with latent renal disease be treated with magnesium, high magnesium levels could very easily be attained.

From a clinical standpoint, it is advisable to reduce or to abstain entirely from the use of neuromuscular blocking agents in pre-eclamptic patients receiving magnesium therapy.

The curare-like effect of magnesium has been well established. ${ }^{22.23}$ In patients suffering from myasthenia gravis, myasthenic syndrome, pro. gressive muscular dystrophy and associated diseases, both skeletal muscle and cardiac function may become impaired, resulting in a hypersensitivity of affected muscles to both neuromuscular blocking agents and magnesium. Therefore special caution should be exercised if magnesium therapy is utilised under these conditions.

Magnesium causes peripheral vasodilation. Potentiation of this effect during anaesthesia is a real possibility, and anaesthetic agents such as the barbiturates, eugenols, butyrophenones, halothane, enflurane, muscle relaxants and nar- cotics, which can depress cardiac function both centrally and peripherally, must be used judiciously in anaesthetizing patients receiving magnesium therapy.

\section{Discussion and conclusions}

Since the description of the striking symptomatology of magnesium deficiency in the experimental animal by Kruse, et al. in 1932,24 low serum magnesium values have been reported in many clinical disorders.

At present there is considerable evidence to support the view that low magnesium levels in cardiac muscle can contribute to sudden death from myocardial ischaemia and infarction. This may account for unexplained deaths during anaesthesia.

Part of this paper deals with basic myocardial metabolism and magnesium interaction and it should be re-emphasized that depletion of cardiac muscle magnesium resulting from ischaemia, anoxia, or the use of cardiotoxic drugs during anaesthesia may result in mitochondrial and ultimate myocardial fibre necrosis.

Because mitochondrial enzyme systems concerned with oxidative phosphorylation are activated by magnesium, and since the administra tion of magnesium salts has been shown to reverse many of the changes in animal models of heart disease, ${ }^{25.26}$ it would be reasonable to suggest that accurate determination of magnesium levels be done as routinely as sodium and potassium determinations and that the electrocardiogram be more closely scrutinized for the possible detection of magnesium deficiency.

\section{SUMMARY}

The role of magnesium in myocardial metabolism and the effects of magnesium deficiency on myocardial contraction and the electrocardiogram have been described. The causes of a magnesium deficiency have been tabulated and the symptoms and signs coupled with suggested guidelines for treatment of magnesium deficiency have been discussed in some detail.

Finally, the inter-relationship between magnesium and the mitochondrial enzyme systems concerned with oxidative phosphorylation is stressed. The early detection of magnesium deficiency by routine methods is imperative for the prevention of abnormal cardiac metabolism and the maintenance of the functional and structural integrity of cardiac muscle during anaesthesia. 


\section{RÉSUMÉ}

Dans le cours de sa pratique habituelle, l'anesthésiologiste doit fréquemment anesthesier des malades présentant une atteinte coronarienne documentée ou inconnue. Le magnésium intervient activement dans la contraction mitochondrique normale en formant le complexe magnésium-ATP. Il joue un rôle important dans le maintien de l'intégrité de la mitochondrie et dans la conservation du potassium dans la cellule myocardique. En cas d'hypomagnésie myocardique secondaire à l'ischémie, à l'anoxie ou à l'emploi d'agents cardiotoxiques, on observe une nécrose de la fibre mitochondrique.

L'identification pré-opératoire des déficits en magnésium et leur traitement pourraient protéger le myocarde contre une nécrose possible et prévenir des troubles du rythme.

L'influence du taux du magnésium sur le métabolisme myocardique et sur le tracé électrocardiographique, ainsi que les effets de l'hypomagnésémie sont discutés. Les auteurs revoient également les causes et la symptômatologie de l'hypomagnésémie et proposent des mesures thérapeutiques appropriés.

\section{REFERENCES}

1. Hillis, C.D. \& Braunwalo, E. Myocardial ischaemia. N.E.J.M. 269: 971-977, 1034-1041, 1093-1096 (1977).

2. Braunwald, E. Control of myocardial oxygen consumption: physiologic and clinical considerations. Am. J. Cardiol . 27: 416-432 (1971).

3. SEELIG. M.S. Myocardial loss of functional magnesium. Part I. Effect on mitochondrial integrity and potassium retention. In: Myocardiology, edited by $E$. Bajusz and G. Rona. Baltimore: University Park, I: 615 (1972).

4. HegGtveit, H.A., et al. Magnesium content of normal and ischaemic human hearts. 7th Internat. Congress of Clinical Pathology, Montreal, July 13-19, 153 (1969).

5. Chipperfield, B. \& Chipperfield, J.R. HeartMuscle magnesium, potassium and zinc concentrations after sudden death from heart disease. Lancet 2: 293 (1973).

6. Janke, J., Fleckenstein, A., et al. Prevention of myocardial $\mathrm{Ca}$ overload and necrotization by $\mathrm{Mg}$ and $K$ salts or acidosis. Recent Advan. Stud. Cardiac Strict. Metabol. 6: 33 (1975).

7. Krasner, B.S. \& Girdwood, R. The use of oral magnesium chloride (slow releasing) in open-heart surgery with special reference to arrhythmias and recovery times. Abstracts of Scientific Papers, A.S.A. Meeting, Chicago, 589-590 (1978).

8. VITALE, J.J., et al. Effect of magnesium - deficient diet upon puppies. Circ. Res. (2) (2): 387-394 (1961).

9. Virale, J.J., ef al. Magnesium deficiency in the cebus monkey. Circ. Res. 12(6): 642-650 (1963).

10. ONO, I. The effect of varying dietary magnesium on the electrocardiogram and blood electrolytes on dogs. Jap. Circ. J. 26: 677-685 (1962).

11. SCham Rorh, L. An introduction to electrocardiography. 3rd ed. Blackwell Scientific Publications, p. $175(1966)$.

12. Lipman, B.G., Massie, E., \& Kleiger, R.E. Clinical scalar electrocardiography. Year Book Medical Publishers, p. 570 (1972).

13. SCHWARTz, P.J. Cardiac sympathetic innervations and the sudden infant death syndrome. Am. J, Med. 60: 167-172 (1976).

14. WACKER, W.E.C. \& PARISI, A.F. N.E.J.M. 278: 712 (1968).

15. Shlis, M.E. Experimental human magnesium depletion. Medicine 48: 61 (1969).

16. Chapda, K.D. Lichstein, E. \& Gupta, P. Hypomagnesemia and refactory cardiac arrhythmia in a non-digitalised patient. Am. J. Cardiol. 31: 98 (1973).

17. Thoren, L. Acta Chirurgica Scandinavia, Suppl. 306 (1963).

18. FLINK, C.B. Therapy of magnesium deficiency, Ann. N.Y. Acad. Sci. 1962: 901 (1969).

19. RANDALL, R.E., ef al. Hypermagnesemia in renal failure, etiologic toxic manifestations. Ann. Int. Med. 61: 73 (1964).

20. Giesecke, A.H., Jr., Morris, R.E., Dal.ton, M.D., \& STEPHEN, C.R. Of magnesium muscle relaxants, toxemic parturients, and cats. Anesth. Analg, (Cleveland) 47: 689 (1968)

21. Ghonheim, M.M. \& LoNG, J.P. The interaction between magnesium and other neuromuscular blocking agents. Anesthesiology 32: 23 (1970).

22. ENOBACK, L. The pharmacological actions of magnesium ions with particular reference to the neuromuscular and cardiovascular system. Pharmacol. Rev. 4: 396 (1952).

23. DeL CASTILLO, I \& ENGBACK, L The nature of neuromuscular block produced by magnesium. $J$. Physiol. 124:370 (1954).

24. KRUSE, et al. Studies on magnesium deficiency in animats. I. Symptommology resulting from magnesium deprivation. J. Biol. Chem. 96: 519-539 (1932).

25. LEHR, D. et al. Possible roles of magnesium loss in the pathogenesis of myocardial fiber necrosis. Recent Advan. Stud., Cardiac Struct. Metabol. 6: 43 (1975).

26. Fedelesova, M., et al. Prevention by $\mathrm{K}^{+}, \mathrm{Mg}^{++}$ Asparate of isoproterenol-induced metabolic changes in the myocardium. Recent Advan. Stud. Cardiac Struct. Metabol, 6: 59 (1975). 